\title{
Strategies for Achieving ICT Literacy \& Proficiency in the Rural Primary and Secondary Schools in Ghana
}

\author{
Eldonna L. May*
}

\author{
Might K. Abreh ${ }^{\dagger}$
}

\begin{abstract}
In order to be productive members of African society, as well as responsible world citizens, the continent's next generation of leaders requires a full suite of knowledge and skills to compete in national, international, and global markets. The core of this knowledge base rests in the STEM and STEAM fields (Science, Technology, Engineering, Arts, and Mathematics). The technology component - through ICT (Internet Computing Technology) - fosters research, discovery, communication, collaboration, and idea exchange among the other disciplines. It enables individuals to conduct business globally; and on local and national levels, leveraging myriad aspects of socio-economic and cultural prosperity. ICT literacy is mandated for all primary and secondary school students both by the African Deans Education Forum ("ADEF") and UNESCO's EFA (Education for All) goals for the African diaspora, as well as by the local Ministries of Education; however, resources and funding are limited with larger funding appropriations allocated to urban areas with pre-existing infrastructure. Thus, schools in rural, underserved communities present special situations relative to meeting the mandate due to insufficient or non-existent infrastructure, access, and training that requires ancillary initiatives over and above those currently provided in order to insure educational equality with their urban counterparts. This paper presents a synthesis of the issues and indicators systems causing the disenfranchisement in rural and underserved communities of Ghana in ICT deployment and usage. Consequently, the authors developed a framework of strategies to address and correct the issue of disenfranchisement in ICT literacy and proficiency in Ghana's rural primary and secondary schools.
\end{abstract}

Keywords: ICT literacy, digital citizenship, technology proficiency, ICT policies.

\section{Background}

The role of ICT in advancement of economic wellbeing and prosperity of nations is not in contention. By means of ICTs citizens could become productive members of society, as well as assume roles that befit those of Ghana's next generation of leaders. To do this requires a full suite of knowledge and skills to compete at national, regional, and global markets. The potential to engage ICTs in the modern work and operational space is engineered by the essential knowledge base in the STEM and STEAM fields (Science, Technology, Engineering, Arts, and Mathematics). The technology component - through ICT (Internet Computing Technology) - fosters research, discovery, communication, collaboration, and idea exchange among the other disciplines. It enables individuals to conduct business globally, as well as on local and national levels, leveraging myriad aspects of

\footnotetext{
*Wayne State University, 4841 Cass Avenue, Detroit, MI 48202, USA. Email: elmay@wayne.edu

${ }^{\dagger}$ Centre for Educational Research, Evaluation and Development, University of Cape Coast,

Cape Coast, Ghana. Email: might.abreh@ucc.edu.gh
} 
socio-economic and cultural prosperity. ICT exerts a great influence upon all areas of our daily lives, possessing the ability to enrich and deepen skills, to motivate and engage learners, to interrelate educational and work-life experiences, to promote entrepreneurship, and to foster new strategies in teaching and learning.

ICT literacy is mandated for all primary and secondary school students both by the African Deans Education Forum (ADEF) and its attendant UNESCO EFA (Education for All) goals for the African diaspora, as well as by the Millennium Development Goals (MDG), the Economic Commission for Africa, the Sustainable Development Goals (SDG), and by local Ministries of Education. All of the foregoing entities have stated that the ability to gain access to and use ICT is not a luxury, but a necessity for humanistic and economic growth; however, resources and funding for deploying ICTs with the limited appropriations largely allocated to urban areas with pre-existing infrastructure. In 2011, a United Nations report recognized the importance of Internet access, stating it should be a priority for all states to ensure citizens can get online: "the unique and transformative nature of the Internet enables individuals to exercise their right to freedom of opinion and expression, (and) a range of other human rights, and to promote the progress of society as a whole" (SOS Children's Villages UK, 2014). Thus, schools in rural, underserved communities present special situations relative to meeting the mandate due to insufficient or nonexistent infrastructure, access, and training that requires ancillary initiatives over and above those currently provided in order to [bring them on] par with their urban counterparts. This paper provides the framework and strategies to address and correct the issue of disenfranchisement in ICT literacy and proficiency in Ghana's rural primary and secondary schools.

Herewith a situational example of the problem at hand: Written by Michael Jackson and Lionel Richie in 1985, "We Are the World" is a song and charity single originally recorded by the super-group United Support of Artists (USA) for Africa. The Quincy Jones-produced single for the album We Are the World sold more than 20 million copies and is one of a small number of singles to have sold at least 10 million copies internationally. While enjoying commercial success, the song received mixed reviews from journalists, music critics, and the public. Music fans appreciated hearing racially and musically diverse recording artists singing together on one track, and were pleased to purchase "We Are the World", in the knowledge that their money supported a worthwhile charitable organization. Other individuals, including many commentators in the rock music press, were disappointed that the song did not challenge listeners as to why famines occur in the first place, and felt that the lyrics were self-aggrandizing. The situation with ICT literacy and proficiency programs in Africa is similar: the words to the "song" sound familiar and resonate with us, and we agree that there is a systemic problem for which change is warranted; yet, 15 years after the institution of the EFA Goals not one country has successfully met the standard with respect to ICT in schools and so like those who purchased "We are the World," we are disappointed with the outcome.

Improved primary and secondary education is essential to the creation of effective human capital in any country (Evoh, 2007) and the need for ICT cannot be overstated. Technology competence is equally necessary and desirable in virtually every field of endeavor, including agriculture and farm management. Such applications and use benefits 
improving the educational system and provides students with a value-added education. A technologically adept workforce leads to growth with the potential to improve all sectors of the economy. Schools find it necessary to "train the trainer" and refresh educators' skills to increase their knowledge of ICT and provide the best possible experience for their students. There are volunteer organizations that will sponsor ICT professionals and educators' visit African schools and teach ICT competencies in primary and secondary schools on a short term basis - ranging from two days to two weeks - but no real, viable long-term solutions to the root cause of the difficulties.

The Education for All (EFA) movement is a global commitment to provide quality basic education for all children, youth, and adults. EFA was the theme of the World Conference on Education held in Jomtien, Thailand in 1990. At that conference it was concluded that education was a fundamental human right; the need for universal access to education was therefore emphasized. The Jomtien conference resulted in the World Declaration on Education for All: Meeting Basic Learning Needs and this achievement was measured according to the level of performance under six key education goals. Some of the goals included expanding early childhood care; Universal Primary Education by the year 2000; improvement in learning achievement; reduction of the adult illiteracy rate to one-half its 1990 level by the year 2000, with sufficient emphasis on female literacy, expansion of provisions of basic education and training in other essential skills required by youth and adults; increased acquisition by individuals and families of the knowledge, skills and values required for better living, and sound and sustainable development (UNESCO, 1990).

At the June 2003 African Summit of the World Economic Forum held in Durban, South Africa, the New Partnership for African Development (NEPAD) launched the e-Schools Initiative, intended to equip all African high schools with ICT equipment including computers, radio and television sets, phones and fax machines, communication equipment, scanners, digital cameras, and copiers, among other things. It also meant to connect African students to the Internet. The NEPAD capacity-building initiative carried a 10year timeline, with the high school component being completed in the first five years. Three phases were contemplated for the project, with 15-20 countries in each phase. The staggered phases would benefit approximately 600,000 schools. The goal of the initiative was to impart ICT skills to young Africans in primary and secondary schools, and to harness ICT to improve, enrich, and expand education in African countries (Aginam, 2006). As of November 2015 the target milestones of the project have not been met; in fact, NEPAD has scored the level of African continent students' experience with ICTs and their proficiency in using the technologies as "very low." Fifty-five percent of students within the continent stated that they had no experience at all in using computers (Adomi \& Kpangban, 2010). The same applies to the EFA goals and the MDGs related to ICT. The eight MDGs sought to focus international assistance on crucial issues facing humanity.

Ghana is one of the 189 United Nations Member States that is committed to help achieve the MDGs by 2015, which included "Education for All" - universal primary education - and promoting gender equality and empowerment of women formed part of the MDGs. This situation places her well to defend the right to education and opportunities to its entire citizenry. However, the current state of affairs seems to indicate that rural Ghanaian children are mostly disadvantaged (Osabutey, 2017). Therefore, this paper 
seeks to uncover issues causing the disenfranchisement in rural and underserved communities of Ghana in ICT deployment and usage and providing a strategy to address and correct the issue of disenfranchisement in ICT literacy and proficiency in Ghana's rural primary and secondary schools.

\section{Approach to the Paper}

The research design employed for this paper mainly relates to interpretive framework based upon quantitative and qualitative methods incorporating an exhaustive literature review in the Sub-Saharan-African regional and those that are specific to Ghana (Elliott \& Timulak, 2005). The authors took into consideration a systematic review of related procedures for examining computers and ICT literacies in the Sub-region in general but Ghana in particular. Information sources on ICT literacy and proficiencies were interrogated by means of analysis of anecdotal evidences available in forms such as, government papers, reports, case studies and memoires. The evidence gathered were thematically described to posit the direction and state of ICT literacies and proficiencies in Ghana. The bibliographic evidence was reviewed using an evaluation protocol for potency and impact of available ICT resources vis-a-vis usage and management of the resources. In consideration of the available evidence around resource availability and usage a proposed strategy for improving ICT literacies and proficiency was proposed for adoption in rural primary and secondary school systems in Ghana.

\section{Findings and Discussions}

Findings revealed that the conventional African school environment (compulsory public education for grades K-10) provides neither opportunity nor training in using ICT, and that $75 \%$ of teachers have little or no training and expertise with respect to ICT educational applications. Primary factors hindering the use of ICTs include first and foremost, infrastructure, connectivity and access, non-integration into the curriculum, poor perception of ICT among teachers and administrators, inadequate or absent ICT policy, lack of line item budget allocations for ICT, insufficient ICT manpower in the schools, limited or absent ICT skills among teachers, inadequate or outdated educational software, shortage of ICT maintenance professionals, and student apathy toward ICT. Limited or poor infrastructure ranks as the most important factor and confirms that, despite best efforts of NEPAD, EFA and MDGs, ICT development and application are not well established. According to Schmid (2015) more than 40\% of Africa's population resides in areas not serviced by telecom, resulting in ICT connectivity challenges. Also included under the heading of infrastructure and cited as the second highest challenge is the lack of adequate ICT facilities in schools. Insufficient numbers of computers and peripheral devices prohibit ICT usage by teachers and limit the opportunity to incorporate ICT applications into the curriculum. Likewise, students do not enjoy the benefit of being able to use hardware and educational software: in some instances several learners must share a single computer, or in a worst case scenario, the equipment is outdated or broken. 
The absence of electricity or frequent outages ranks third in the list of impediments to successful implementation of ICT in schools. This is most common in rural and remote areas, where regular use of ICT facilities relies on a secure energy grid. Inconsistent and/or inadequate ICT policy and project implementation strategies ranked fourth in the list of challenges. Even though computer education was mandated both at the international level by the EFA goals, MDGs and NEPAD, as well as at the government level across the African diaspora some 15 years ago, computers that were distributed by governments to high schools were never used for computer education of the students. Little or no effort was made to distribute computer equipment to state government or private schools; and, although the government planned to integrate ICTs into the school systems and provide schools with infrastructure, the results have been middling, at best. As a result, many schools do not yet offer ICT training programs. The NEPAD e-Schools project, expected to serve approximately 600,000 African schools, has likewise encountered challenges primarily because governments have been slow in the creation, development and implementation of national ICT policies (Aginam, 2006). One of the primary reasons for this is that despite ICT's ever-increasing role in globalization and e-commerce, it remains a low financial priority in most educational systems in Africa when compared to numerous competing development priorities (Evoh, 2007).

Secondary, but equal factors encumbering the introduction and implementation of ICT curricula range from inadequate ICT manpower in the schools, the cost of ICT facilities and hardware, and the poor perception of ICTs among teachers and administrators. This is a very toxic cocktail of factors for ICT growth and development. The devaluation of the teaching profession, combined with a poor perception of the value of ICT makes it difficult to attract knowledgeable, talented ICT teachers and technicians. Internationally, the profession of teaching has become known as a "pink collar" profession and considered less valuable in the workplace than medicine, law, business, and engineering - populated by women and those who do not have the capacity to become physicians, lawyers, and captains of industry. As a result, a broad segment of the teaching population has become apathetic toward their profession and lacks the motivation to assist students in acquisition of computer education. This attitude also fosters another of the challenges: namely, the poor perception of the value of ICT among school administrators and faculty. Even in 2016 there still exists misconceptions and ignorance with respect to the importance and necessity of ICT education and training as it relates to STEM and STEAM applications. For many Africans, ICT remains something unfamiliar and mysterious, rather than viewed as a viable tool for personal and professional growth, national development, globalization and employability. It has been reported that $75 \%$ of the teachers in the NEPAD's e-Schools Project have no or very limited experience and expertise regarding ICT in education (Adomi \& Kpangban, 2010). Further, schools have yet to extensively adopt ITC for teaching and learning. As a result integration of ICT into the school systems has not made a significant impact on learning outcomes, globalization, and employability. Poor policy and implementation strategies, coupled by limited information infrastructure, and inadequate funding stand as barriers to ICT education in the classroom. 


\section{The Case for Ghana}

Historically, Ghana pushed for the ICT concept with the importation of used computers (desk top) that mostly broke down weeks, months and sometimes years after they were installed. At the time, computer importation into Ghanaian schools was not done on policy basis but purely driven by aid support and philanthropic acts of donors. Dankwa (1997) indicated that the situation was not uniform and on top provision favoured schools categorized as premier schools and schools in urban areas. Again, the syllabus that teachers of the ICT in education curriculum promoted at the secondary schools at the time did not have a coordinated platform by the Ministry of Education and its Ghana Education Service. However, dating back as far as 1995, one thing was certain, that is Ghana became the first country in the Sub-Saharan Africa region to have full Internet connectivity (Opoku, 2004); indicating her readiness to venture the field of ICTs as a tool for development. For example, the Ghana Poverty Reduction Strategy Paper (GPRS I \& II) as well as the Education Strategic Plan 2003-2015, the one for 2010 - 2020 all pointed to ICT as a tool for achieving the development of Ghana and bridging the rural-urban divide (Government of Ghana, 2003). According to Opoku (2004) Ghana subscribed to this initiative by an established memorandum of understanding between the Government of Ghana and Microsoft in order for the latter to provide resources to improve ICT education in Ghana. Indicating that there was deliberate attempt for the state structures to harness the potentials of Internet Communication Technologies (ICTs). Regardless of the pockets of effort generated by Ghana and her development partners on the ICT infrastructure procurement and deployment front, there was still huge gap between the rural and urban divide on same (Mangesi, 2007; Sey, 2013; Sarfo, Amartei, Adentwi, \& Brefo, 2011).

This research work builds on the issues surrounding the offering of social justice on the fundamental issues like education that global mandate like the EFA, MDGs, and SDGs pontificates (UNESCO, 2013/2014, 2015). The issue of social justice has been unpacked in this paper to mean to provision of equitable access to ICT resources to all Ghanaian children. There are however studies that show access and equity issues on Ghanaian children and how especially the rural Ghanaian has been served with ICT infrastructure and facilities suggests that there is the divide between provision for the poor and underserved mostly in the rural and deprived areas of Ghana as against their counterparts in the urban places (Abreh, 2015; Ampiah, Fletcher, Davis, \& Abreh, 2012). The Ghanaian parliament passed into law Ghana's ICT for Accelerated Development (ICT4AD) policy that activated the structures for ICT use nationwide. It is based on this document that a new document targeting the education sector was prepared (Government of Ghana, Ministerial ICT Policy statements, 2005). Among other things the document for education sector considered how to integrate ICTs in schools in Ghana (Abreh, 2011). No doubt the engagement of last years of the 20th century dovetail into the preparation of the ICT policy for Ghana. It was refreshing that a committee was set up by the Ministry of Education to develop an ICT in education policy framework was part of their mandate charged to provide means of standardizing ICT resources for all schools and promote ICT as a learning tool in the school curriculum at all levels (Malcolm \& Godwyll, 2008). 


\section{Context ICTs in Education in the Ghanaian Education Sys- tem}

The ICTs policy on paper proffer hope for access and equity but on the ground things is a little different. Children in undeserved and hard to reach places are more often than not less privileged compared to their counterparts in urban centers (Abreh, 2015). Furthermore, Aduwa-Ogiegbaen and Iyamu (2005) contend that there is wide disparity in ICTs use between rural and urban schools. The ICT agenda in the Ghanaian education system is seen as an inter-ministerial activity originally spearheaded by the development partners and other private sector agencies for close to two decades. ICT related enterprises in both public and private schools have almost becoming ubiquitous in urban places as against those of rural Ghana (Mfum-Mensah, 2003). In instances where such ICT resources are available they are usually saddled by inadequate computers and other ICTs tools, poor connectivity to the internet, little to no amount of electrical energy sources with some schools resorting to the use of car batteries; lack of appropriate technical manpower in ICT curricula.

Republic of Ghana (2008) reported on a paper that was carried out to first review as well as assess the ICT in Education Initiatives in Ghana involving twenty initiatives were selected and their impact assessed, it was found that although there were gains ultimately in the Ghanaian education regime some challenges remains. The challenges were related with the projects and initiatives themselves. It was identified that about ten of the initiatives had been launched as pilots with none expanded to have a national coverage and character. The report stated among others that the schools were poorly selected resulting in duplication of activities and hence inability to measure adequately the effect of the projects and programs - the report notes affected most of the rural Ghanaian schools. Additionally, uncoordinated policy stream at all levels (schools, districts, national) for the integration of ICT in the education curriculum; dependency on outward financial inflows that mostly seized after the project ended or after the funds depleted; rejuvenating of obsolete ideas and equipment as it were in the name of aid and support or assistantship, community and state ownership of such initiatives were mostly loose leading to the untimely death of the initiatives; and most of all there were trained teachers and personnel to man the ICT in education initiatives that were running.

Ghana has incorporated a full complement of policies, reports and initiatives that have global and national character including regional, and community-wide initiatives that have emphasized the role of education and training in the wider development agenda of the country (Republic of Ghana, 2008). For example, the Government of Ghana has agreed in principle and policy that ICT has a bearing on the performance of the education sector. At the international, regional, national and sector levels, such policies have emphasized the role of education and training in achieving the wider development goals and agenda. Ghana also happens to be party to major initiatives in ICT in education including the Millennium Development Goals (MDGs), the Dakar Education Goals, the World Summit on the Information Society, all calls for building an inclusive Information Society without boundaries, without favor and without jurisdictional differences. The list extends to 
NEPAD and its e-schools initiative that has been discussed elsewhere in this paper.

In sum, most of the ICT in education activities and initiatives happened as short-term or one-time engagements and not as systemic occurrences. The various ICT in education initiatives were not thoroughly regulated because the preponderance of them were spinoffs of Non-Governmental Organizations and other developmental aid-in-kind partners that procured and deployed the resources. In the same vein, the type of capacity building that provided resources to school management and ICT teachers were not sustainable initiatives, but consisted only of orientation and sessional workshops. Again, the majority of the efforts were geared toward the deployment of ICTs to these facilities through delivery of computer hardware and software, and the construction of ICT laboratories for students. In many instances the issue of equitable distribution of the computers and computer laboratories turned an ugly face toward the rural child. Again beyond physical resource deployment, the issue of capacity building for ICT in education teachers could be noticed, however the situation in the rural compared to the urban divide could best be described as appalling. Access remains below the standards and numbers mandated. Though comparatively better, the concerns remain for tertiary level institutions. Additionally, there have been several private sector initiatives to create community-based ICT centers. These, however, have been largely confined to urban areas with few available examples of how they have been used to support educational objectives.

\section{Rural Schooling and ICT Education in Ghana}

This section of the paper presents a synopsis of data and information on how rural schooling coupled with teaching and learning practices in ICT education has evolved. The approach used is based on a review of anecdotal evidence and past empirical research evidence that lay claims to the assumptions and hypothesis of a yet to be promoted project in the rural ICT initiative. In order to best accomplish this task, the authors reviewed past ICT projects that occurred in the rural part of Ghana vis-a-vis those in that occurred in urban settings. For example, past research and project report outputs have resulted in a number of implementation strategies related to challenges encountered in launching new startups in ICT education studies and projects.

The challenge of ICT in education does not border on program implementation alone in Ghana, but as well on other factors including the kind of leadership (administrative and instructional cadres) that is practiced in schools. Observation reveals that in the Ghanaian education system head teachers or school principals are the only officers entitled to offices. In effect, the weight attached to their management and leadership style cannot be undermined. For instance, how well do school and system management shows effort to make activities sustainable even after the project phase has elapsed needs to place before school management and leadership.

ICT tools and resources depend on operative platforms in order to work. For instance, dry cells, electrical or solar energy are used to power most of the time to power the available technological tools; without which radio, laptops, computers, mobile phones and television would not be powered. Whereas efforts were made by several Ghanaian to 
watch television and listen to radio programs in the pre 21st century era using car batteries, similar unsustainable platforms are not suitable for the 21st century learning and education society.

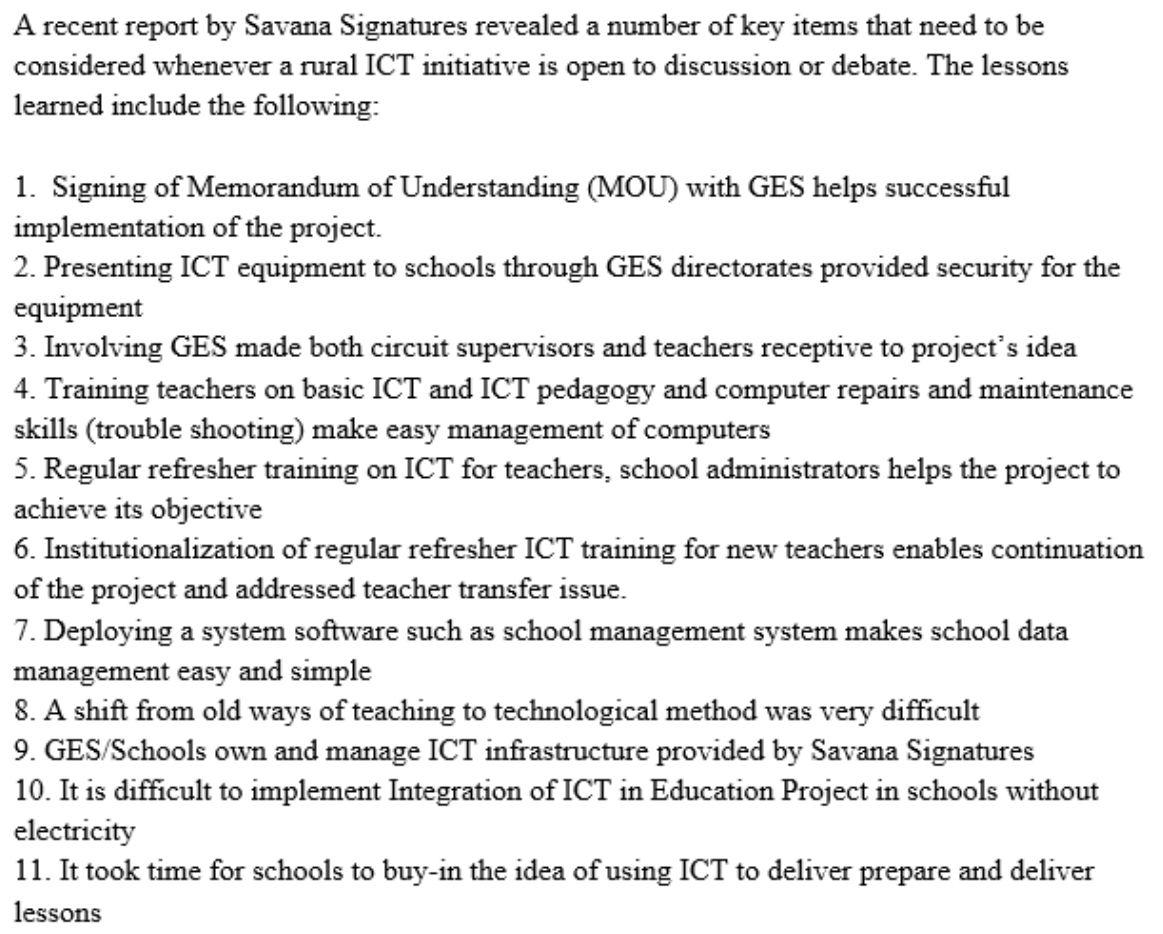

Indeed the 2011 and 2015 (amended) education policy in Ghana seem to suggest that there is need for improved infrastructural resourcing of rural areas to meet the provision that is going to schools. Besides, on the infrastructure front another issue that merit general attention of people in academia and their counterparts in school and pupil services management is the one regarding access and equity in the proliferation of ICT in Education programs by guaranteeing "logistical deficiencies, locational incentives are fully addressed to attract and sustain personnel in the rural and per-urban areas to give considerable equal opportunity for learners, given that there is a unified educational system with a common examination system" (Ministry of Education, 2015).

The infrastructural support systems for ICT in education seem to suggest that the issue is not only deficiency-ridden, but also security imbued. This creates a high-risk scenario for ICT tools for education deployment to rural communities and underserved Ghanaian populace in general, but more important for the next generation of Ghanaian citizens. The Ministry of Education (2015) revised ICT in education policy stop gapped, among other things, unavailability of appropriate ICT compliance building that are security hardy (cit- 
ing burglar proof, lighting etc.) or electrical power infrastructure to support school computer laboratories for ICT in education programs. This document postures a limitation in the scope and coverage of such ICT in education programming and offers insight into why sustainability and scalability are not immediate options or luxury for rural Ghanaian if no deliberate and orchestrated attempt is made to forestall equity on the roll-out front.

The most important stakeholder in education process is the learner (who is at the center of the education production function). It must be recognized that the fact that a medium is proclaimed ubiquitous does not mean that access is accomplished, and that the end user has been reached. The availability of any medium does not guarantee access. For instance, a 100 percent availability of Internet or 75 percent availability of television is equivalent to Internet users or viewers having access to the platform that these media provide. Indeed, all technology platforms transmit over one medium or another (satellite, wi-fi, broadband connections). Besides, others need intervening media, such as electricity or telephone service, to work effectively in the village or the hamlet; without electricity or phone lines, there will not be access to any computer services.

There are other factors in Ghana and globally that compel the learner to be put in the center of affairs. These include, ownership and control of the technology product or platform with little to no doubt about it its capabilities. Seen from this standpoint, technology is driven through systems (context) and people and all three work hand in hand.

Studies have shown that the success, failure, and the way forward for ICT systems and structures are dependent upon the scope of environment for which the ICT systems needs to be applied. In a special case of context, thought is given to functionality, usability and utility by Beynon-Davies (2002). Works by Delone and Mclean (2002) broadly point to the diffusion role of context whereas the work of Heeks (2002) specifically promotes environment of occurrence in the developing countries. The wide diversity in terms of ICT systems provisions and platforms in the most developing countries including and wide segregated areas that is mainly inhabited by the underserved people. This paper concedes that simply procuring and deploying equipment is insufficient to bring about the desired educational change and enhanced learning outcomes. The goal must be a deliberate attempt to blend a nationally coordinated strategy design, dissemination, and sharing of best practices in the domain of Technology Pedagogical Content Knowledge areas with the view to improve the quality of teaching and learning in schools (Gichoya, 2005). It also is important to consider the perception, attitude, teacher, and pedagogical approach to Technology Pedagogical Content Knowledge regime helps bridge the divide between the rural and urban locations. For example, which approaches work best in rural/remote locations, and which allow for higher end diffusion of technology needs to be taught for Ghana rural people?

\section{Conclusion}

It is increasingly becoming clear that ad hoc measures do not solve the problem of ICT related illiteracies prevalent in most developing and countries including and especially 
so for its rural underserved population. Besides, short-term donor sponsored events have little to no scalability and sustainability effects and should not be the panacea for ending the regime of "rural ICT deficiency syndrome". This paper does not advocate omitting development partners in the process, but the authors strongly recommend that such arrangements should have national and decentralized structures involved through definitive agreements and partnerships of scalability and sustainability of the interventions. Such definitive plans could create opportunities for integrating the various factors highlighted in this paper and determine how they cumulatively encourage equitable quality access to ICT literacies in education that is desired by the state system of education.

This investigation reveals that launching ICT literacy and proficiency initiatives is co-dependent upon the indicators revealed in this paper. The authors contend that the best strategic plan of action culminates in action-oriented dialogue with key stakeholders about how the input systems collaborate with processes to create the desired level of ICT literacy and proficiency. Therefore, the next logical step in the process is a rigorous innovation driven strategy that is inspired by community and grassroots structures to create action and implementation plans to address the issue of disenfranchisement on the ICT literacy and proficiency front in Ghana's rural primary and secondary schools. The authors envision the next generation of learners - regardless of their location - to be the locus of attention for a technology driven tomorrow.

What is needed is a sustainable approach that will integrate education and training, infrastructure improvements, funding for ICT hardware, software, and maintenance under the mantle of a unified international ICT policy mandate for the continent. These initiatives must be implemented at the primary school level, with an eye toward creating equity between rural, remote, and urban schools. Primary school children should be learning and developing both the intellectual capacity and fine motor skills associated with ICT proficiency at a young age to insure optimum expertise by the time they reach Grade 10 and make the life-altering decision to further their education in senior secondary school and beyond. This can only be accomplished with the full cooperation of government representatives, business entities, and educationalists working together to create a brighter future for the world's children. Through proposal writing and public appeals for resources, combined with sustainable financial support and with the skill and expertise of trained professionals in ICT teaching and learning, it must be communicated that the other sectors of our globalized society will bask in the reflective glow of an ICT-literate and proficient population in Ghana and the African diaspora. 


\section{References}

Abreh, M. K. (2011). Preparing pre-service teachers to integrate educational technology in the colleges of education curriculum in the Central Region of Ghana. International Journal of Research in Computer Applications and Management, 1(10), 18-23.

Abreh, M. K. (2015). Influence of wing schools' complementary basic education programme on provision of educational opportunities in northern region of Ghana (Unpublished doctoral dissertation). University of Nairobi.

Adomi, E. E., \& Kpangban, E. (2010). Application of ICTs in Nigerian secondary schools. Library Philosophy and Practice (e-journal). Retrieved from http://digitalcommons.unl.edu/cgi/viewcontent.cgi?article= 1353\&context=libphilprac

Aduwa-Ogiegbaen, S. E., \& Iyamu, E. O. S. (2005). Using information and communication technology in secondary schools in Nigeria: Problems and prospects. Educational Technology \& Society, 8(1), 104-112.

Aginam, E. (2006). NEPAD scores students' ICT Education in Africa low. Retrieved from http://www.vanguardngr.com/articles/2002/features/ technology/tec527092006.html

Ampiah, J. G., Fletcher, J. A., Davis, E. K., \& Abreh, M. K. (2012). Enhancing access to education for out-of-reach children in hard to reach communities in Ghana: The ACE experience. Ghana Journal of Education: Issues and Practice, 4(1), 1-24.

Beynon-Davies, P. (2002). Information systems: An introduction to informatics in organisations. Basingstoke: Palgrave.

Dankwa, W. A. (1997). Schoolnet: A catalyst for transforming education in Ghana. Retrieved from https://www.isoc.org/inet 96/proceedings/c6/c6_1.htm

Delone, W. H., \& Mclean, E. R. (2002). Information systems success revisited. Retrieved from https://pdfs.semanticscholar.org/3bfo/ dc52885a44a69a522fbbbe2ad6ea72215c56.pdf

Elliott, R., \& Timulak, L. (2005). Descriptive and interpretive approaches to qualitative research. New York: Oxford University Press.

Evoh, C. (2007). Policy networks and the transformation of secondary education through ICTs in Africa: The prospects and challenges of the NEPAD e-schools initiative. International Journal of Education and Development using ICT, 3(1), 68-84.

Gichoya, D. (2005). Factors affecting the successful implementation of ICT projects in government. The Electronic Journal of E-government, 3(4), 175-184.

Heeks, R. (2002). Information systems and developing countries: Failure, success, and local improvisations. The Information Society, 18(2), 101-112.

Malcolm, E., \& Godwyll, F. (2008). Diffusion of information communication technology in selected Ghanaian schools. Retrieved from https://www.icafrica.org/ fileadmin/documents/Knowledge/DFID/Diffusion\%200f\%20ICTs\% 20 in 20 selected\%20Ghanaian\%20schools.pdf

Mangesi, K. (2007). Survey of ICT and education in Africa: Ghana country report. Retrieved from http://www. infodev.org 
Mfum-Mensah, O. (2003). Computers in Ghanaian Secondary Schools: Where does equality come in. Current Issues in Comparative Education, 6(1), 40-49.

Ministry of Education. (2015). ICT in education policy. Accra: Republic of Ghana.

Opoku, R. A. (2004). Ghana and ICT: Strides, Challenges and the way forward. Retrieved from http://www.ghanaweb.com/GhanaHomePage/features/ Ghana-and-ICT-Strides-Challenges-and-the-way-forward-54098\#

Osabutey, A. (2017). Assin asamankese pupils using stones as mouse for ICT studies. Retrieved from https://www.primenewsghana.com/general-news/assin -asamankese-students-learn-ict-using-stones.html

Republic of Ghana. (2008). ICT in education policy. Accra: Government of Ghana.

Sarfo, F. K., Amartei, A. M., Adentwi, K. I., \& Brefo, C. (2011). Technology and gender equity: Rural and urban students' attitudes towards information and communication technology. Journal of Media and Communication Studies, 3(6), 221-230.

Schmid, A. (2015). Get Africa connected - the important role of technology in rural farming. Retrieved from https://www.one.org/us/2015/07/08/get-africa -connected-the-important-role-of-icts-in-rural-farming/

Sey, J. (2013). Access to and use of ict infrastructure in teaching and learning: A comparative study of rural and urban public junior high schools in South municipality. masters degree thesis. Retrieved from http://ugspace.ug.edu.gh:8080/

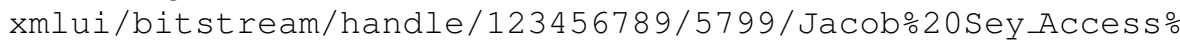
20 to 20 and $\% 20$ Use $200 f \% 20$ ICT 20 Infrastructure 20 in 20 Teaching $\%$ 20 and $\% 20$ Learning. $\div 20 \mathrm{~A} \div 20$ Comparative 20 Study $\% 200 f \div 20$ Rural $\%$ 20 and $\% 20$ Urban\%20Public 20 Junior $20 \mathrm{High} \% 20 \mathrm{Schools} \% 20$ in $\% 20$ the 20GA 20 South $\% 20$ Municipality_2013.pdf? sequence=1\&isAllowed=y

SOS Children's Villages UK. (2014). How is ICT improving education in East Africa? Retrieved from http://www.soschildrensvillages.org.uk/news/ archive/2014/08/ict-education-east-africa

UNESCO. (1990). Meeting basic learning needs: A vision for the 1990s. Retrieved from http: / / unesdoc. unesco.org/images/0009/000975/097552e.pdf

UNESCO. (2013/2014). Teaching and learning: Achieving quality for all. Retrieved from http: / / unesdoc. unesco.org/images/0022/002256/225660e.pdf

UNESCO. (2015). Education for all 2000 - 2015: Achievements and challenges. Retrieved from http: //unesdoc.unesco.org/images/0023/002322/232205e.pdf 